\title{
MNEs Vertical Linkages: The Experience of Vietnam after Malaysia
}

\author{
Axèle Giroud \\ $\underline{\text { Axele.giroud@mbs.ac.uk }}$
}

This is a pre-print (non-publisher's document). Please cite the published article:

Giroud, Axèle (2007), "MNEs' vertical linkages: The experience of Vietnam after Malaysia," International Business Review, 16 (2), 159-176. doi:10.1016/j.ibusrev.2006.11.003

MNEs Vertical Linkages: The Experience of Vietnam after Malaysia

\begin{abstract}
:
Knowledge transfer from multinational corporations to local suppliers in host developing countries have been shown to be substantial and a strong contributor to the competitive upgrading of firms in host economies. Using data provided by multinational subsidiaries, this paper compares the activities of multinationals in both Malaysia and Vietnam. Malaysia is considered because its experience with foreign direct investment is long-standing (compared to Vietnam) and useful recommendations can be drawn for Vietnam, allowing for the transition nature of the Vietnamese economy. The objectives of the paper are two-fold: to demonstrate the potential for knowledge transfer between multinationals and their suppliers in
\end{abstract}


both Malaysia and Vietnam; and to build upon this discussion to suggest avenues for Vietnam to maximise beneficial linkages from MNEs.

Key words - multinational enterprises, vertical linkages, local suppliers, technology transfer, knowledge, Vietnam, Malaysia

\section{Introduction}

The impacts of MNEs on host economies have been studied carefully in the literature since the 1960s, but one aspect that still needs better understanding is the way foreign firms influence the development of local firms (Moran, 2005), notably through their local purchasing behaviour. Buyer-supplier linkages have recently attracted increasing attention from scholars and policy makers because of the role they play in host countries' development, essentially by supporting the local supply industry and transferring knowledge to local suppliers. Porter (1990) emphasises the central place of supporting industries in generating competitive firms and countries. With this in mind, one of the key consequences of the presence of foreign firms in one sector in host countries is, therefore, the impact they potentially have on the supporting industry, and specifically the impact on the upgrading of suppliers through linkages and related technology transfer. Linkages by multinationals in host economies have received considerable attention in the literature (Rodríguez-Clare, 1996; Blomström et al, 2000; UNCTAD, 2001; Giroud, 2003), yet, the mechanisms through which vertical linkages take place are still not well understood. While the study of linkages is well established in the economic development literature (Rodríguez-Clare, 1996; Markusen and Venables, 1999; Lin and Saggi, 2005), it has not been integrated fully within the theoretical strands of multinationals' activities (Meyer, 2004).

In common with existing theoretical models (e.g. the models developed by Markusen and Venables (1999) and Lin and Saggi (2005), incorporating technology transfer to a two-tier production structure), the paper makes the assumption that multinationals have positive effects on the development of indigenous firms through the creation of vertical linkages and sourcing of intermediate products locally (other affects notwithstanding), and also assumes that the multinational technology is superior to that of its competitors. Further, the paper draws from existing literature on vertical linkages and the literature on local technological capabilities (Lall, 1996; 2002). Numerous empirical studies have been conducted on these topics, with some authors examining the level of local purchase by MNEs in host economies (McAleese and McDonald, 1978; O'Farrell and O'Loughlin, 1981; Turok, 1993; Driffield and Noor, 1999; Görg and Ruane, 2001; UNCTAD, 2001; Belderbos et al., 2001) and how these vertical linkages impact on specific industries (Kelegama and Foley, 1999; Dries and Swinnen, 2004), while others focus on the issue of MNE-supplier technology and knowledge transfer (Halbach, 1989; Wong, 1991; Supapol, 1995; Crone and Roper, 2001; UNCTAD, 2001; Blalock, 2003; Giroud, 2003; Ivarsson and Alvstam, 2005). Many studies also focus on the issue of wider technology spillovers by multinational firms in host economies (see for instance, Sjöholm, 1999; Blomström et al., 2000; Blomström and Kokko, 2001; Görg and Strobl, 2001; Javorcik, 2004; Günther, 2005, among others).

To date, there has been no investigation of the potentially beneficial impact of MNEs on local suppliers through transfer of knowledge and technology in the specific case of Vietnam. In this respect, existing studies on transition economies focus on Eastern European countries (for instance, Javorcik (2004) analyses the spillovers from FDI through vertical linkages in Lithuania; Lorentzen, Møllgaard and Rojec (2003) study technology transfer in the automotive industry in Poland, the Czech Republic, Hungary, Romania, Slovakia and Slovenia; Dries and Swinnen (2004) focus on the Polish dairy industry). Because they have only recently faced external competition, many firms in transition economies are in dire need 
of restructuring and upgrading of capital, technology and management (Dries and Swinnen, 2004).

The study of the impact of FDI in a transition economy such as Vietnam, which has received substantial flows of foreign investment since the mid-1990s, provides useful insights into foreign firms' relations with local suppliers. The paper analyses firm-level data collected in Malaysia and Vietnam to, first, assess the existence of technology and knowledge transfer from MNEs to local suppliers and, second, to compare the experience of the two countries. The comparison with Malaysia is particularly useful because it is a neighbouring country which is part of the same regional grouping (ASEAN) as Vietnam but having been host to FDI for far longer, MNEs have already developed substantial vertical linkages with its supplier industries (Rasiah, 1995; Driffield and Noor, 1999; Giroud, 2003; Cantwell and Iguchi, 2005). Other studies have drawn upon the lessons that can be learnt by Vietnam from Malaysia in terms of economic development (Mirza and Giroud, 2004).

\section{Literature and propositions}

This paper focuses on the creation of linkages by MNEs in host economies. The two common types of linkages created are vertical (or backward) and horizontal (forward) (UNCTC, 1981; Dunning, 1993; Lall, 1996; Caves, 1996; Rodríguez-Clare, 1996; Blomström et al., 2000; UNCTAD, 2001). Vertical linkages represent the relations established with supplier firms, whereas forward linkages comprise relations established with business customers in the host economy. The concept of linkages was first established by Hirschman (1958), then used in firm-level studies (Lim and Fong, 1982; Lall, 1996).

In the context of developing economies, the debate originated with the need to understand whether MNEs did indeed create linkages with local firms, as opposed to operating in enclaves, with no immediate connections to the host economy (see Glass et al. 2002 for a recent discussion on the contribution of Hirschman's work). Linkages can be broadly defined as direct relationships established by firms in complementary activities, which are external to pure market transactions and essential to the functioning of any normal industrial market (Lim and Fong, 1982: 586). Of the linkages created by MNEs, the most important ones are those established with local suppliers of parts components and services (Lall, 1996: 60). For this reason, vertical linkages have received increased attention in the academic literature, with increasing numbers of studies addressing the issue of spillovers generated through vertical linkages.

In a world with imperfect competition and economies of scale, linkages have positive effects on the firms concerned through spillovers (Görg and Ruane, 2001). Local supply linkages forged by MNEs go beyond pecuniary exchange and bring technical, but also informational, financial, organizational and managerial externalities (Lim and Fong, 1982; UNCTAD, 2001; Croner and Roper, 2001; Ivarsson and Alvstam, 2005). MNEs often engage in transfer activities so as to minimise the price of sourcing, and to increase competition in upstream industries (Blalock, 2003). Recent case studies discuss in great depth how MNEs engage in transfer activities that are beneficial for the development of local suppliers. For instance, Ivarsson and Alvstam (2005: 1340) explain that a substantial proportion of the domestic suppliers, with the exception of Mexico, have been provided with technological assistance by Volvo as part of mutual business relationships.

Examples of how linkages benefit local suppliers are found in the electronics industry across East Asia (Hobday, 1995), whereby foreign affiliates initiate supply relationships with local firms and improve their quality, productivity, and product diversity. Foreign affiliates, similarly to other final-good producers help bring forth a greater variety of specialized inputs, thus generating a positive externality to other final-good producers (Rodríguez-Clare, 1996: 
853). MNEs create demands for local inputs, strengthen the competitiveness of local suppliers through local externalities; and these suppliers, in turn, generate forward linkages in the economy. This paper, in common with the model developed by Markusen and Venables (1999), assesses first and second-order vertical linkages effects. MNEs (or final good producers) purchase intermediate goods, this allows local suppliers to benefit from economies of scale and to reduce their costs. Both inter- and intra-sectoral effects are generated. Adding the assumption that MNEs' technology is superior to that of firms in host economies (see Lin and Saggi, 2005), the prospect of technology transfer from MNEs to local firms enhances further the positive impact on host economies.

Empirical studies focusing on case studies and firm-level data have shown that, with time, linkages assist in upgrading domestic suppliers, through increased technological and other capabilities and subsequent spillover effects on the rest of the economy (Kelegama and Foley, 1999; Giroud, 2000; UNCTAD, 2001; Scott-Kennel, 2004). McAleese and McDonald (1978) found that vertical linkages increased over time in Ireland, not only because of the various production processing stages within foreign affiliates, but also because foreign firms were keen to attract and develop local suppliers, local industrial policy, and autonomous developments arising out of the growth of the entire manufacturing industry.

In a country such as Malaysia, that has been the recipient of FDI since the 1960s, one would therefore expect that, with time, the nature of the relationships established between foreign affiliates and local suppliers changes. Similarly, Lorentzen, Møllgaard and Rojec (2003), in their study of technology transfer and diffusion in the automotive supply chains in Eastern Europe, suggest that researchers should investigate what influences the competences of individual firms, how technological learning translates into the upgrading of competences over time, and where and why national innovation systems fail to provide an environment conducive to indigenous innovation.

Drawing from these earlier studies, one can conclude that change occurs as a result of factors related to the MNE itself, the growth of the industrial base, and local or national policies. Host governments consider vertical linkages as beneficial to the development of local suppliers, and therefore an increasing number of countries have adopted policies to promote not only local sourcing, but also the deepening of relationships between foreign and local firms. Such linkage promotion policies are, of necessity, highly context specific and need to be adapted to the specific circumstances prevailing in each host economy (UNCTAD, 2001, p. xxiii). Malaysia has adopted pro-active policies aimed at enhancing inter-firm linkages in the industrial sector (Jomo, 2001), and some regional initiatives have proved successful in encouraging training and human resource development, particularly in the electronics sector. Hence, it is expected that:

Proposition 1: There is potential for knowledge and technology transfer from foreign affiliates based in Malaysia and Vietnam to their local suppliers.

Proposition 2: The nature of the relationship between foreign affiliates and their suppliers changes over time.

A number of factors indicate that MNEs' supply relations in Vietnam will differ from those in Malaysia. First, although both countries engaged in economic liberalization programmes in 1986 (the New Development Policy in Malaysia and the Doi Moi policy in Vietnam), Malaysia had encouraged FDI since the late 1960s and its success in attracting foreign investment is reflected in inward flows. Over 1986-91, the annual average FDI inflows were of US\$ 1,605 million in Malaysia, compared to US\$ 68 million in Vietnam (UNCTAD, 1998: 364). In contrast, Vietnam became attractive for FDI in the 1990s. By 2004, FDI inward stock 
in the country reached US\$29,115 million, up from US\$20,596 in 2000 and US\$ 1,650 million in 1990 (UNCTAD, 2005: 311). Nevertheless Malaysia has retained its differential advantage with FDI inward stocks of US\$ 46,291 million in 2004, compared to US\$10,318 in 1990. Malaysia's experience with FDI pre-dates that of Vietnam, and its government has devised elaborate policies to attract and to benefit from FDI (Giroud, 2003:112). Secondly, Vietnam's economic environment reflects the transition from a centrally planned economy to a market economy. Both private and state-owned firms face a lack of experience of market capitalism. Private firms are also often subjected to an unfavourable environment of discriminatory incentives and rules with respect to finance, investment, tax and trade (Giroud, 2005: 40). Despite the positive changes introduced with the Enterprise Law in 2000, it is expected that the level of competitiveness of local suppliers in Vietnam differs from that of suppliers in Malaysia, and subsequently the type of relationships established by foreign firms with their suppliers in both economies differs. For these reasons, it is expected that:

Proposition 3: Because Vietnam is a transition economy, there is a difference in the level of knowledge and technology transfer from MNEs depending on whether they are located in Malaysia or Vietnam.

Through repeated interactions with local suppliers, and the process of knowledge and technology transfer, MNEs in host developing economies can contribute to the enhancement of local supplier's business capabilities and competitiveness. Thus, it is proposed that in both economies:

Proposition 4: MNEs' knowledge and technology transfer to local suppliers contribute to the improvement of local suppliers' capabilities.

\section{Sample characteristics}

The target group for this study are multinational firms operating in either the electronics/electrical sector or in the textiles and garment sector. These two industries are pillars in the economies of countries across Southeast Asia, and recipient to a substantial share of foreign direct investment in both Malaysia and Vietnam. A semi-structured questionnaire was used to interview managers in Malaysia and Vietnam ${ }^{\mathrm{i}}$, the objective of the survey being to examine the activities performed by multinational firms and assess vertical linkages established in the host economy. Vertical linkages in the questionnaire were defined to include both backward and forward linkages (this terminology ${ }^{\mathrm{ii}}$ is used similarly by other authors such as Belderbos et al 2001, Günther 2005), but this paper focuses on backward linkages and related knowledge and technology transfer. 49 interviews conducted in Malaysia and Vietnam during 2002 are analysed. Table 1 summarizes some of the key characteristics of the sample for the recent study, and provides a comparison with a similar earlier study conducted by the author of multinational firms in the electronics/electrical sectors in Malaysia in 1996 (Giroud, 2003).

Table 1 Characteristics of MNEs in Malaysia and Vietnam (1996 and 2002)

\begin{tabular}{|c|c|c|c|}
\hline & $\begin{array}{c}\text { Malaysia } \\
(\mathbf{1 9 9 6 )}\end{array}$ & $\begin{array}{c}\text { Malaysia } \\
(\mathbf{2 0 0 2})\end{array}$ & $\begin{array}{c}\text { Vietnam } \\
(\mathbf{2 0 0 2})\end{array}$ \\
\hline & $N=95$ & $N=27$ & $N=22$ \\
\hline Industry (Frequency) & & \\
\hline Electronics/electrical & 95 & 25 & 11 \\
\hline
\end{tabular}




\begin{tabular}{|c|c|c|c|}
\hline Textiles \& Garments & 0 & 2 & 11 \\
\hline \multicolumn{4}{|c|}{ Nationality of ownership (\% of plants) } \\
\hline Japan & 51.6 & 37.0 & 31.8 \\
\hline USA & 28.4 & 25.9 & 4.5 \\
\hline Europe & 9.5 & 18.5 & 13.6 \\
\hline 3 NIEs & 8.4 & 14.8 & 36.4 \\
\hline ASEAN & 0.0 & 0.0 & 13.6 \\
\hline Others & 2.1 & 3.7 & 0.0 \\
\hline \multicolumn{4}{|c|}{ Firm ownership (\% of plants) } \\
\hline Wholly-owned & 76.8 & 66.7 & 54.5 \\
\hline Majority-owned & 17.9 & 22.2 & 45.5 \\
\hline Minority-owned & 5.3 & 11.1 & 0.0 \\
\hline \multicolumn{4}{|c|}{ Year of establishment (\% of plants) } \\
\hline Prior to 1970 & 0.0 & 11.1 & 0.0 \\
\hline $1970 \mathrm{~s}$ & 14.8 & 37.0 & 0.0 \\
\hline $1980 \mathrm{~s}$ & 65.3 & 44.4 & 9.1 \\
\hline $1991-1995$ & 20.0 & 7.4 & 54.5 \\
\hline $1996-2000$ & 0.0 & 0.0 & 22.7 \\
\hline $2001-2002$ & 0.0 & 0.0 & 13.6 \\
\hline \multicolumn{4}{|c|}{ Number of employees (\% of plants) } \\
\hline Less than 200 & 18.7 & 15.4 & 90.9 \\
\hline $200-1000$ & 49.5 & 23.1 & 9.1 \\
\hline over 1000 & 31.9 & 61.5 & 0.0 \\
\hline \multicolumn{4}{|l|}{ Export orientation } \\
\hline $80 \%$ or more & 64.5 & 63.0 & 50.0 \\
\hline $20-79$ & 29.0 & 18.5 & 18.2 \\
\hline less than 20 & 6.5 & 18.5 & 31.8 \\
\hline \multicolumn{4}{|c|}{ Firms that import all their material inputs (\% of plants) } \\
\hline & 12.687 .4 & 7.492 .6 & 9.1 \\
\hline \multicolumn{4}{|c|}{ Mean of local sourcing of material inputs (\%) } \\
\hline & N/A & 34.7 & 20.4 \\
\hline
\end{tabular}

The sample reflects the industrial composition of both countries, with a bias towards electronics/electrical in Malaysia (see Table 1). While the Textile and garment industry developed in Malaysia in the 1970s, part of it has now relocated to lower-cost production location, including Vietnam. For many years the fastest growing activity in Malaysia has been the Electronics and electrical industry. In contrast, the Textile and garment industry remains predominant in Vietnam and its exports are second only to those from the crude oil sector. For ASEAN as a whole, over 1995-2004, the key source investing regions/countries were the EU (29.3\%), the USA (17.3\%), ASEAN (13.0\%), Japan (13.7\%), and the Asian NIEs $(8.2 \%)^{\mathrm{iii}}$. Foreign firms interviewed in the survey reflect this composition, as well as the relative significance of textiles/garments and electronics/electrical in Malaysia and Vietnam. Reflecting the FDI experience of both countries, MNEs have been in operation in Malaysia for longer and are, therefore, larger in size and more often wholly-owned compared to those in Vietnam.

The mean level of local sourcing of material inputs is just over a third of total sourcing in Malaysia and one fifth in Vietnam. The reasons for the difference are multi-fold. Foreign firms have entered more recently in Vietnam, and have not yet developed fully their network of local suppliers. They often still rely heavily on imports, particularly from the home country. In addition, half of the firms interviewed in Vietnam manufacture textiles and/or garments. Supply patterns in this industry differ from electronics/electrical, often as a result of 
the dominant roles played by major buyers (Dicken, 2007). For instance, focusing on garment manufacturers in Sri Lanka, Kelegama and Foley (1999: 1451) mention that in some circumstances, buyers and garment manufacturers have strong reasons for choosing a supplier from outside Sri Lanka. First, this can be because mass production of a product takes place at various sites. Second, this could be the result of special relations with particular suppliers (for instance if they are part of the same conglomerate). Thirdly, some MNEs might be large enough to negotiate special arrangements with regional suppliers. Hence, in the context of global strategies and international buying groups specific to the garments industry, the demand for domestic inputs may be altered.

\section{Empirical methodology}

As mentioned earlier, the first research aim is to assess the existence and circumstance behind the transfer of knowledge and technology from MNEs to their suppliers in both Malaysia and Vietnam. The methodological approach adopted in this paper starts by measuring the stock of knowledge in a foreign subsidiary by investigating the transfer of various advanced production, managerial or organizational methods ${ }^{\text {iv }}$. This evaluation assesses 19 transfer practices focusing on a range of production and training issues, and foreign affiliates' managers were asked to indicate the extent to which the foreign firm was involved in knowledge transfer activities to local suppliers. Managers discussed with the researchers the interactions with suppliers that led to knowledge transfer. Such transfers can subsequently support local suppliers in their improvement of competences and capabilities. Foreign affiliates interact with their suppliers intentionally (for instance through specific training offered to suppliers) or incidentally (by way of regular meetings and communications

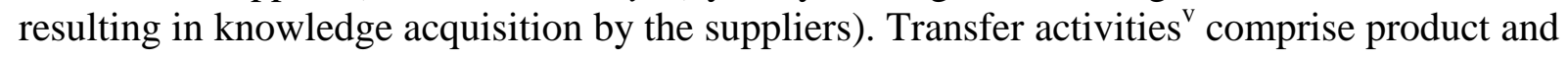
process technology related to the manufacturing of material inputs for the subsidiary (11 items), and knowledge transferred through training (8 items) (for full details on each item, please see Giroud, 2003: 217-225). Questions targeted the potential impact of the MNEs on the technical and production efficiency of suppliers, with some consideration to the potential change in organizational and strategic orientation included within the training transfer activities.

An underlying assumption behind knowledge transfer occurring between foreign firms and local suppliers is that the suppliers' capabilities improve as a result of the interaction with foreign customers. To assess this assumption and measure the impact of knowledge transfer activities on the capabilities of local suppliers, managers were invited to provide their perceptions on how suppliers had improved as a result of dealing with their firm, using a fivepoint rating scale (ranging from 'significant improvement' to 'no improvement at all'). The limitation of such a method is acknowledged, indeed, as a detailed analysis of individual suppliers would provide a more objective and accurate assessment of the impact of MNEs on suppliers. Such studies have been conducted, but it was beyond the means and scope of this particular research.

\section{MNEs' knowledge transfer through vertical linkages}

The paper aims to present the scope for knowledge exchange between foreign affiliates and their local suppliers, as this determines the potential learning and acquisition by local firms and thus enhances the positive outcome of MNEs' activities in host developing economies. Table 2 summarises knowledge exchange, showing the share of firms engaging in transfer frequently with their local suppliers.

MNEs in the sample engage in moderate levels of local sourcing (34\% of total direct input purchased in Malaysia and $20 \%$ in Vietnam, as shown in Table 1), but, importantly, there is evidence of knowledge transfer from foreign affiliates to their local suppliers. Significant 
proportions of firms frequently engaging in transfer activities confirms Proposition 1 MNEs engage in a wide range of activities that facilitate the transfer of knowledge to suppliers. MNEs most commonly provide suppliers with specifications about standard material/components, together with physical or technological specifications of the inputs purchased. Generally, it is less common for foreign affiliates to advise their suppliers on managerial techniques ('support in supplier business management' and 'professional training for the suppliers' managers' are undertaken frequently by less than a quarter of affiliates). Similar results were found in the case of Northern Ireland (Crone and Roper, 2001: 543), where the most common knowledge transfer activities were to give suppliers advance notice of production plans and ongoing quality audits of suppliers' products, while advice on strategic or financial aspects and techniques were undertaken by only a quarter of Northern Ireland-based MNE plants.

In the case of Malaysia, the 1996 and 2002 samples indicate that knowledge transfer activities have changed in nature over time. Transfer of production processes is still the most frequent type of transfer, but more firms frequently engage in joint designs of inputs with local suppliers or in joint settlement of operations requirement in 2002. This change occurred because capabilities of local suppliers have improved, firms have developed further their relationships with their local suppliers and it is likely that, as foreign firms have been established in Malaysia for a long time, their role and independence within the global network has increased. Affiliates offer 'off-the-job' training more frequently (through seminars at the subsidiary or at the suppliers), and professional training for the suppliers' managers are more common, while on-the-job training has decreased. Changes in the frequency of various types of transfer confirm Proposition 2, suppliers are more actively involved with MNEs (this is particularly noticeable when joint design of materials/components and joint settlement of operations requirements occur).

Although the firms involved in the study were not identical, the samples allow us to identify changes in the nature of knowledge exchange between firms, and to further consider the difference in terms of the length of time spent by foreign firms in the host economy. Correlation results indicate that the longer the foreign firms have been in operation in either Malaysia or Vietnam, the more frequently they engage in knowledge transfer activities. Table 2 shows positive correlation for a number of knowledge transfer activities with the number of years spent by foreign firms in the host country.

The evidence in Table 2 also shows sharp differences between knowledge transfer activities conducted by firms in Malaysia, compared to those located in Vietnam. This is reflected across all knowledge transfer activities, with the percentage of firms frequently engaging in these transfers being much higher in the case of Malaysia (whether this be with the 1996 or 2002 samples). T-test statistics confirmed the significant difference in the level of local sourcing depending on whether firms were in Malaysia or in Vietnam, with a negative relationship in the case of Vietnam. However, there is no statistical difference in the knowledge transfer activities between firms whether they are established in Malaysia or in Vietnam. The gap in levels of transfer is therefore explained not by factors specific to Vietnam, but other factors, notably the presence of firms in the textile and garments sector. Thus, Proposition 3 is only partly confirmed; interactions between foreign affiliates and their local suppliers are less developed in Vietnam than they are in Malaysia, but the difference in the type knowledge transferred is not country-specific.

Earlier results confirmed that the longer foreign firms remain in a host economy, the more they engage in knowledge sharing activities with their local suppliers. FDI flows in Malaysia have risen substantially since the mid-1980s, as opposed to the early 1990s in Vietnam; therefore the difference in knowledge transfer activities can be partly explained by the difference in FDI experience between the two countries. Firms' purchasing patterns differ 
significantly depending on whether they operate in Malaysia or in Vietnam. Only a fifth of firms in Vietnam mention that their share of input purchased locally has increased sharply, against over 40 percent for firms in Malaysia; although future trends are positive and more firms anticipate a sharp increase. First, this can result from the fact that firms have not been in operation for very long, and still depend heavily on their parent company. Two firms during interviews clearly indicated that they relied heavily on their parent firms for supply, as they had not yet developed their own supply network in Vietnam. Secondly, foreign firms expressed concerns about the local supply base. Six firms were concerned about the lack of available local suppliers for various essential inputs, and seven judged quality levels of inputs produced by locally-owned firms as inadequate. Finally, a third of firms in Malaysia mentioned that more than half of their local suppliers were locally-owned, against only $17 \%$ in Vietnam. One firm forecast an increase in local sourcing because a foreign-owned supplier was setting up operations locally, indicating that the intended increase in local sourcing would be the result of exchanges amongst foreign subsidiaries as opposed to between the affiliate and local firms. 
Table 2 Percentage of MNEs with frequent knowledge transfer to their suppliers

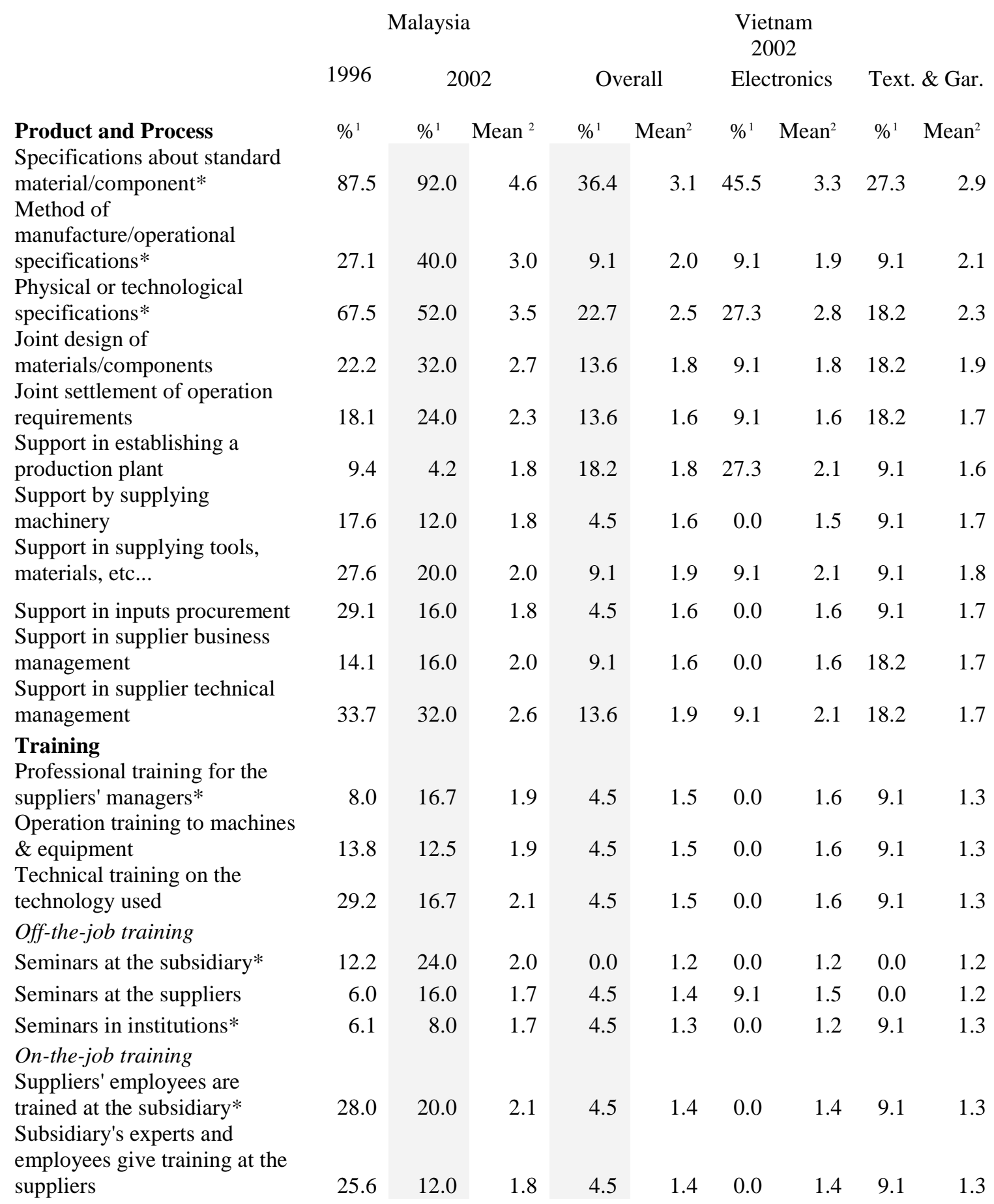

Note: Figures for 1996 are based on a 3-point likert scale, they show the percentage of firms reporting that they transfer each type of knowledge 'frequently'

1) Figures show the percentage of firms reporting that they transfer each type of knowledge 'frequently' or 'very frequently'

2) This figure is a mean of a five-point rating scale ( 1 being 'never' to 5 'very frequently')

* Indicates a significant positive correlation between the frequency of knowledge exchange and the age of the subsidiary in the 2002 sample (Malaysia and Vietnam combined) 


\section{Perceived impact of MNEs' knowledge transfer on local suppliers}

The main assumption underlying the analysis of knowledge transfer from MNEs to local suppliers is that local firms will benefit from interaction with foreign firms and improve their own business capabilities as a result. Although no financial data on suppliers and their performance is presented, managers' perceptions (as shown in Table 3) indicate significant improvement in suppliers' performance as a result of their regular business with foreign affiliates. This confirms Proposition 4. In the previous section, data pointed to Malaysia's experience with FDI, whereby foreign firms purchase more inputs locally, and also engage more in knowledge transfer activities. Table 3 reflects managers' perception of the improvement of local suppliers after interacting with their firms. Following the variance in purchasing patterns and behaviour, key differences appear in supplier improvement in Malaysia compared to Vietnam. A higher share of managers reported that their local suppliers improved their performance after the foreign firm conducted business with them in Malaysia. Most improvements were achieved for cost, quality and delivery. Significant differences were confirmed statistically for all factors bar two.

Similar steady improvement in terms of product quality and efforts to reduce cost of production were reported in other studies, where MNEs vertical inter-firm linkages were found to be associated with sizeable transfer of technology and knowledge, aiming at improving the quality and timely delivery of parts and components or at improving local firms' employees through training, (Awuah, 1997; Batra and Tan, 2002). In the case of Ghanaian suppliers, for instance, suppliers set up modern machineries to meet the high quality requirement of their foreign buyer (Awuah, 1997: 82); team work between experts from the supplier, the foreign affiliate and its headquarters lead to the joint development and production of new packaging materials; and premiums were awarded to suppliers for good quality achievements.

Improvements in the extent and depth of locally-owned suppliers' interface with their foreignowned customers can come about in various ways, notably by the adoption of supplier support programmes. Such programmes have been found extremely positive in other studies. For instance, Dries and Swinnen (2004: 1532) found that foreign firms, faced with small suppliers unable to make basic investments and restricted in their access to basic inputs due to a variety of market imperfections, foreign investors introduced quality improvement strategies and financial assistance programmes. In the case of the subsidiaries interviewed in this study, although over half of firms in Malaysia have established such programmes, none have been established in Vietnam to date. The slow progress of foreign firms in terms of setting up supplier partnership programmes in Vietnam is not unexpected, given the small share of supply purchased locally, as well as the fact that many suppliers in the country are foreignowned.

One should end by considering the potential detrimental impact MNEs can have on local suppliers. When looking specifically at the cost improvement (and indeed one of the key improvement in the sample is related to cost), one can question the dominant position of the foreign buyer, who can dictate the terms of trade, especially the price of the input. This pricesetting can be against the interest of the local firm, particularly in a developing country context where local suppliers may not have large scale production and thus rely heavily on profit margins to finance technological improvements. MNEs tend to deal with a small number of large suppliers to minimize transaction costs, thereby consolidating their supplier base, this can result in the separation of many small suppliers from their traditional outlets (Dries and Swinnen, 2004:1526). 
Table 3 Perceived impact of MNEs' knowledge transfer on their local suppliers (\%)

\begin{tabular}{|c|c|c|c|c|}
\hline & Malaysia & \multicolumn{3}{|c|}{ Vietnam } \\
\hline & Total & Total & Elect. & $\mathrm{T} \& \mathrm{G}$ \\
\hline Improved performance in terms of Cost* & 88 & 50 & 45 & 55 \\
\hline Improved performance in terms of Quality* & 92 & 73 & 55 & 91 \\
\hline Improved performance in terms of Delivery* & 88 & 50 & 55 & 45 \\
\hline Improved performance in terms of Inventory Control & 80 & 45 & 45 & 45 \\
\hline $\begin{array}{l}\text { Improved performance in terms of Lead Time } \\
\text { Performance* }\end{array}$ & 80 & 41 & 36 & 45 \\
\hline $\begin{array}{l}\text { Improved performance in terms of Continuous } \\
\text { Improvement }\end{array}$ & 72 & 45 & 36 & 55 \\
\hline Improved performance in terms of Technical Skills* & 76 & 50 & 36 & 64 \\
\hline Improved performance in terms of Design & 52 & 36 & 18 & 55 \\
\hline Improved performance in terms of Innovation* & 68 & 27 & 9 & 45 \\
\hline Improved performance in terms of Safety* & 76 & 27 & 9 & 45 \\
\hline Improved performance in terms of Business Focus* & 80 & 32 & 27 & 36 \\
\hline $\begin{array}{l}\text { Improved performance in terms of Commercial } \\
\text { Awareness* }\end{array}$ & 80 & 36 & 36 & 36 \\
\hline Improved performance in terms of Service focus* & 84 & 45 & 36 & 55 \\
\hline Improved performance in terms of Professionalism* & 84 & 50 & 36 & 64 \\
\hline
\end{tabular}

Note: These figures report the percentage of firms indicating that their supplier's improved performance was 'moderate', 'large' or 'very large'. Items highlighted with * are significantly different between Malaysia and Vietnam under ANOVA test $(p<0.10)$ 


\section{Discussion}

The aim of this paper is to compare MNEs supply activities in Malaysia and Vietnam, with a focus on the Vietnamese experience, the lessons that could be learnt from the Malaysian case and the potential benefits that could be obtained by the country (and its firms) from the development of MNE-supplier linkages. The results demonstrate the substantial impact that foreign firms have in both countries through their vertical linkages, with these increasing the longer foreign firms had been established in the economy. Variations in the extent of knowledge transfer were linked to the type of industry, the FDI experience of the host country, MNEs' strategies and subsidiary characteristics and the state of the local supplier base. While managers made no direct mention to the transition nature of the Vietnamese economy, one can question whether linkages would be more extensive in a non-transition economy at a similar level of development; and whether the experience of Malaysia can be replicated in Vietnam.

\section{Malaysia and Vietnam: A development perspective}

First, let us consider the FDI experience. A key assumption adopted in this paper is that FDI contributes to the development pattern of both Malaysia and Vietnam, through the creation of linkages and subsequent knowledge and technology transfer. The impact of FDI depends, to a degree, upon the local competence of firms. Stage or path theories suggest that MNEs are sensitive to the level of economic development of the host economy, which leads to varying types of FDI and multinational activity (Ozawa, 1992; Narula and Dunning, 2000). These theories further explain variance in linkage creation (and purchasing behaviour) between countries by differences in host country conditions and the foreign firms' characteristics. The results discussed in this paper confirm the stage and path theories. Malaysia has reached the second stage in the investment development path (UNCTAD, 2006: 144). It is ahead of Vietnam, both in terms of inward and outward FDI ${ }^{\mathrm{vi}}$, and the competitive effect of inward FDI on domestic firms is therefore expected to be higher. In this context, weaker vertical linkages are anticipated in Vietnam. Yet, one must consider whether the principle of comparative dynamic advantage and related restructuring of economic activity follows a different path for countries in transition such as Vietnam.

\section{Vietnam: A country in transition}

Transition economies distinguish themselves by the predominant role played by the state in the economic and business environment. In the case of Vietnam, some of the distinctive features of MNEs' subsidiaries can be explained by these government policies. Foreign firms in the sample analysed in this paper are more orientated towards the local market (although this is partly related to the size of the Vietnam market), are significantly less likely to be wholly-owned subsidiaries, were established fairly recently (because of concerns about the nature of the Vietnamese political economy), purchase a significantly smaller share of their material inputs from the local market and from locally-owned suppliers (in comparison to Malaysia). These features partly reflect government policies in Vietnam.

First, joint ventures are encouraged as an entry mode, particularly with state-owned enterprises. This impacts upon the strategic choices of MNEs, and creates an imbalance in favour of SOEs as business partners for foreign firms. Second, Vietnam engaged in the Doi Moi policy in the late 1980s and only encouraged foreign investment in the 1990s, later than its neighbour countries in ASEAN; its FDI experience is shorter, and foreign subsidiaries were only recently established. Third, trade agreements with foreign countries were initiated late, the agreement with the U.S. was initiated in 2001 and membership to the WTO took effect as of January, $11^{\text {th }} 2007$. The integration of Vietnam into the world trading system is 
very recent. This explains why many MNEs have primarily invested in Vietnam for the purpose of servicing the local market.

Of course, government policies do not determine the choice of companies' differentiated global strategies, but they do influence comparative advantages and the business environment, which in turn impact upon parent firms' location choices and the position of subsidiaries within the MNEs' international network. In the sample, most foreign affiliates in Vietnam performed manufacturing activities without conducting strategic functions. In contrast, foreign affiliates' strategic duties in Malaysia are limited, but increasing (Edwards et al., 2002). Since greater and more intensive linkage are expected when foreign affiliates perform strategic activities (Giroud and Mirza, 2006), it is likely that the positive impact of foreign affiliates in Malaysia (and with time in Vietnam too) will increase as these affiliates gain enhanced positions and strategic influence within the multinational network.

Finally, managers in the sample deplored the lack of available suppliers able to provide quality products. Some decisions taken by the Vietnamese government in the past have slowed the development of a strong private sector. Resources have been dedicated to the strengthening of the state-owned sector, sometimes to the detriment of private firms. Private firms have found access to finance difficult, restraining their capacity to develop and expand. One should note that Vietnam has witnessed a robust growth of private firms even with an almost total absence of formal institutions to facilitate business (McMilland and Woodruff, 2002: 156), but this has been insufficient to allow private firms to develop a competitive edge in certain sectors, as mentioned by managers of foreign affiliates. The lack of a solid national system of innovation has had consequences for technology development in these local suppliers. Finally, these adverse local competitive conditions act as a disincentive for MNEs to develop programmes that would raise the level of service and quality of local firms.

\section{Vietnam: The way forward?}

This paper showed the way backward linkages evolve over time, as foreign affiliates create stronger business relationships and localise their operations. The comparison of linkages in Malaysia between 1996 and 2002 provided useful insights into the development paths of linkages over time. The type of knowledge shared by the foreign firms evolved towards increasing joint design and operations and more involvement with suppliers' managers. If these were solely a matter of time, one would expect a similar trend in Vietnam in the future. Yet, comparing affiliates' characteristics in Malaysia in 1996 with those of Vietnam in 2002, some key distinctions are apparent, namely related to the ownership structure, the exportorientation and the size. The impact of transition economics on MNEs' activities indicate that unless Vietnam drastically reforms its competitive environment, the potential for linkage development will remain insufficient. The data used in this paper are not perfect, but are sufficiently robust to suggest that Vietnam does not present similar features in its FDI experience as Malaysia did in the late 1990s. It is not too late for Vietnam to catch up, and these findings are valuable for countries further down the path, including Cambodia, Laos, a number of Central Asia economies, for which the FDI experience has only just been initiated.

\section{Conclusions}

The analysis of the data shows that locally-owned suppliers in Vietnam do not yet benefit from foreign firm's superior technology and managerial expertise to the same extent as those in Malaysia. Levels of backward linkages remain small, and little knowledge is being shared by foreign firms with local suppliers. The discussion highlighted some issues related to the transition nature of Vietnam that might explain these limited linkages. Although some of the issues discussed are common to other developing economies, the need to develop further the 
local supply industry and specifically the private sector is more acute in transition economies such as Vietnam.

The specificities of the Vietnamese economic and political systems need to be considered to design an effective promotion programme of vertical linkages. Policies such as local content requirements, rules-of-origin regulations, and other trade-related investment measures have often proved insufficient instruments ${ }^{\mathrm{vii}}$ (Hackett and Srinivasan, 1998; UNCTAD, 2003). Soft policy provisions, whereby MNEs are not operating under mandatory rules, but rather are encouraged to conduct business in a particular way, such as those adopted in Malaysia might be more effective. Of course, the inward FDI policies and trade policies encourage foreign firms' activities in the country, but most urgently, Vietnam must promote its competitive environment and focus on the enhancement of domestic firms' capabilities, for both SOEs and non-SOEs. This will strengthen the potential for linkages and spillovers by MNEs.

Vietnam must first support entrepreneurship and foster the creation of new industries, and new companies, promote private investment (in fixed assets, $R \& D$ and training) so as to consolidate the foundation of the competitiveness of domestic firms. Many local suppliers to MNEs are small-scale, and need to improve upon their production, marketing and distribution systems. In the longer term, some of these weaknesses can be remedied, as was achieved in Malaysia, through partnerships between foreign firms and local suppliers. This will be feasible once the preconditions for linkages creation and knowledge sharing are in place. Only then will foreign affiliates feel the benefits of initiating supplier development programmes, some of these linked to government incentives.

Indeed, with the competitive foundations in place, further policies targeting partnerships and knowledge sharing between foreign firms and local firms can be implemented. In Malaysia, for instance, the government has adopted a cluster-based approach with strong concern for local linkage creation, thereby supporting existing incentives to attract foreign firms. Similar schemes will be useful in Vietnam too, but only once the local supply base has been sufficiently developed.

Finally, the suggestions given above apply to other transition economies, but individual environments differ significantly and the success of linkage promotion measures can only be achieved when contextually specific conditions and policies are in place.

\section{Endnotes:}

\footnotetext{
${ }^{\mathrm{i}}$ The data used in this paper is part of a bigger study (see Mirza et al. 2003), for which a total of 113 companies were interviewed across ASEAN, from "pure" regional headquarters (RHQ) firms with no manufacturing activities to indigenous firms. The core of the analysis relied upon information collected through interviews among 88 manufacturing companies in the 5 host countries. Of these companies, 49 cases are presented in this paper, focusing on Malaysia and Vietnam.

ii A variety of terms have been used traditionally in the literature to describe the activities and interaction by multinational firms in host economies. Vertical linkages can also be referred to as inter-industry linkages (see for instance Belderbos et al., 2001 and Günther, 2005) or some authors describe these as inter-industry linkages. Similarly, in the context of further impact of the multinationals, it is common to differentiate between horizontal and vertical spillovers (Girma et al., 2004) or intra- and inter-industry spillovers (Kugler, 2006)

iii Data extracted from ASEAN Statistical Yearbook 2005: 146, http://www.aseansec.org

iv Such a method was also utilized, stemming from the economic literature on technological diffusion, by Crone and Roper, 2001: 539

v Similar differentiations have been adopted in other studies. For instance, Ivarsson and Alvstam (2005: 1327) use the following:

"Firstly, product-related technology, including the provision of proprietary product know-how, for example, through patents and licenses, the transfer of product designs and technical specifications, technical consultations, and regular feedback on product performance. Secondly, process-related technology transfers that comprise the provision of machinery and equipment, technical support in product planning, quality management, inspection, and testing, as well as advice on tooling, maintenance, product layout, and operations. In addition, TNCs assist their suppliers by transferring organizational and managerial know-how, as well as by offering various forms of training programmes.".
} 


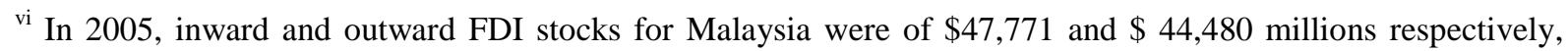
against \$31,135 millions inward FDI stocks and negligible outward stocks for Vietnam (UNCTAD, 2006: 305)

${ }^{\text {vii }}$ For instance, policies on local content requirements were insignificant in explaining local procurement ratios of Japanese firms in host economies in the electronics industry. However, other factors such as quality of infrastructure and the size of host country's components supplying industry are important determinants (Belderbos et al., 2001).

\section{Bibliography}

Awuah, G.B. (1997). Promoting Infant Industries in Less Developed Countries (LDCs): a Network Approach to Analyse the Impact of the Exchange Relationships between Multinational Companies and their Indigenous Suppliers in LDCs' Efforts to Boost Infant Industries' Development. International Business Review, 6(1): 71-87.

Batra, G., \& Tan, H.W. (2002). Inter-firm linkages and productivity growth in Malaysian manufacturing, Cornelle University. '

Belderbos, R., Capannelli, G., \& Fukao, K. (2001). Backward vertical linkages of foreign manufacturing affiliates: evidence from Japanese multinationals. World Development, 29(1): 189-208.

Blalock, G., \& Gertler, P. J. (2003). Technology from foreign direct investment and welfare gains through the supply chain, Cornell University.

Blomström, M., \& Kokko, A. (2001). Foreign direct investment and spillovers of technology. International Journal of Technology Management, 22(5/6): 435-54.

Blomström, M., Kokko, A., \& Zejan, M. (2000). Foreign Direct Investment: Firm and Host Country Strategies. Basingstoke, New York: Macmillan.

Cantwell, J., \& Iguchi, C. (2005). Effects of backward linkages to local suppliers' development path: The case of the Malaysian electrical and electronics industry.In Giroud, A., Mohr, A.T. \& Yang, D., Editors, Multinationals and Asia: Organizational and Institutional Relationships. London, New York: Routledge.

Caves, R.E. 1996. Multinational Enterprise and Economic Analysis. Cambridge: Cambridge University Press, 2d Edition.

Crone, M., \& Roper, S. (2001). Local learning from multinational plants: Knowledge transfers in the supply chain. Regional Studies, 35(6): 535-48.

Dicken, P. 2007. Global Shift: Mapping the Changing Contours of the World Economy. $5^{\text {th }}$ Ed. London, Thousand Oaks, New Delhi: Sage Publications.

Dries, L., \& Swinnen, J.F.M. (2004). Foreign direct investment, vertical integration, and local suppliers: Evidence from the Polish dairy sector. World Development, 32(9): 1525-44.

Driffield, N. \& Noor, A.H.M. (1999). Foreign direct investment and local input linkages in Malaysia. Transnational Corporations, 8(3): 1-24.

Dunning, J. H. (1993). The governance of Japanese and U.S. manufacturing affiliates in the U.K.: Some country-specific differences. In Kogut, B., Editor, Country Competitiveness: Technology and the Organizing of Work. Oxford, New York: Oxford University Press.

Girma, S., Görg, H., \& Pisu, M. (2004). The role of exporting and linkages for productivity spillovers from FDI, Research paper series: Globalisation, productivity and technology. University of Nottingham.

Giroud, A. (2003). Transnational Corporations, Technology and Economic Development: Backward Linkages and Knowledge Transfer in South East Asia. Cheltenham, Northampton: Edward Elgar. 
Giroud, A. (2005). Vietnam in the regional and global transnational corporations value chain. Chp 3 in Giroud A., Mohr, A.T., \& Yang, D., Editors. Multinationals and Asia: Organizational and Institutional Relationships. London, New York: Routledge.

Giroud, A., \& Mirza, H., (2006). Multinational enterprises and local input linkages in Southeast Asia. Transnational Corporations., 15(3): 1-32.

Glass, A.J., \& Saggi, K. (2002). Multinational firms and technology transfer. The Scandinavian Journal of Economics, 104(4): 495-513.

Görg, H., \& Ruane, F. (2001). Multinational companies and linkages: Panel data evidence from the Irish electronics sector. International Journal of the Economics of Business, $8(1): 1-18$.

Görg, H. \& Strobl, E. (2001). Multinational companies and productivity spillovers, a metanalysis. The Economic Journal, 111: F723-39.

Günther, J. (2005). Technology spillovers from foreign investors in transition economies - are the effects still expected? Economic and Business Review for Central and South - Eastern Europe, 7(1): 5-24.

Hackett, S.C., and Srinivasan, K. (1998). Are there spillovers from direct foreign investment? Evidence from panel data for Morocco. Journal of Development Economics, 42: 51-74.

Halbach, A.J. (1989). Multinational Enterprise and Subcontracting in the Third World: A Study of Inter-industrial Linkages. Geneva: ILO, International Labour Office Multinational Enterprises Programme.

Hirschman, A. O. (1958). The Strategy of Economic Development. New Haven, CT: Yale University Press.

Hobday, M. (1995). Innovation in East Asia: The Challenge to Japan. Cheltenham: Edward Elgar.

Ivarsson, I. \& Alvstam, C.G. (2005). Technology transfer from TNCs to local suppliers in developing countries: A study of AB Volvo' s truck and bus plants in Brazil, China, India, and Mexico. World Development, 33(8): 1325-44.

Javorcik, B. S. (2004). Does foreign direct investment increase the productivity of domestic firms? In search of spillovers through backward linkages. The American Economic Review, 94(3): 605.

Jomo, K.S. (2001). Southeast Asia's Industrialization: Industrial Policy, Capabilities and Sustainability. Basingstoke, New York: Palgrave.

Kelegama, S. \& .Foley, F. (1999). Impediments to Promoting Backward Linkages from the Garment Industry in Sri Lanka. World Development, 27(8): 1445-60.

Kugler, M. (2006). Spillovers from foreign direct investment: Within or between industries? Journal of Development Economics, 80(2): 444-77.

Lall, S. (2002). Linking FDI, technology development for capacity building and strategic competitiveness. Transnational Corporations, 11(3): 39-88.

Lall, S. (1996). Transnational corporations and economic development. In UNCTAD, editor, Transnational Corporations and World Development. London, Boston: International Thomson Business Press.

Lim, L.Y.C. \& Fong, P.E. (1982). Vertical linkages and multinational enterprises in developing countries. World Development, 10(7): 585-95.

Lin, P. \& Saggi, K.. (2005). Multinational firms and backward linkages: A critical survey and a simple model.In Moran, T. H. , E. M. Graham, \& M. Blomström, editors, Does Foreign Direct Investment Promote Development? Dulles: Institute for International Economics.

Lorentzen, J., Møllgaard, P., \& Rojec, M. (2003). Host-country absorption of technology: Evidence from automotive supply networks in Eastern Europe. Industry and Innovation, 10(4): 415-32. 
Markusen, J. R., \& Venables, A. J. (1999). Foreign direct investment as a catalyst for industrial development. European Economic Review, 43(2): 335-56.

McAleese, D. \& McDonald, D. (1978). Employment growth and the development of linkages in foreign-owned and domestic manufacturing enterprises. Oxford Bulletin of Economic and Statistics, 40: 321-40.

McMillan, J., \& Woodruff, C. (2002). The central role of entrepreneurs in transition economies. Journal of Economic Perspectives, 16(3): 153-70.

Meyer, K. E. (2004). Perspectives on multinational enterprises in emerging economies. Journal of International Business Studies, 35(4): 259-77.

Mirza, H., \& .Giroud, A.. (2004). Regionalisation, FDI and Vietnam: Lessons from other ASEAN countries. Journal of the Asia Pacific Economy, 9(2): 223-48.

Mirza, H., Giroud, A., Jalilian, H., Weiss, J., Freeman, N.J., \& Than, M. (2003). Regionalisation, Foreign Direct Investment and Poverty Reduction: The Case of ASEAN. Bradford: University of Bradford.

Moran, T. H. (2005). How does FDI affect host country development? Using industry case studies to make reliable generalizations. In Moran, T. H. , E. M. Graham, \& M. Blomström, editors, Does Foreign Direct Investment Promote Development? Dulles: Institute for International Economics.

Narula, R., \& Dunning, J.H.. (2000). Industrial development, globalization and multinational enterprises: New Realities for developing countries. Oxford Development Studies, 28(2): 141-67.

O' Farrell, P. N., \& O' Loughlin, B.. (1981). The impact of new industry enterprises in Ireland: An analysis of service linkages. Regional Studies, 15(6): 439-58.

Ozawa, T. (1992). Foreign direct investment and economic development. Tansnational Corporations, 1(1): 27-54.

Porter, M. (1990). The Competitive Advantage of Nations. New York: The Free Press, Macmillan.

Rasiah, R. (1995). Malaysia.In Supapol, A.B., editor, Transnational Corporations and Backward Linkages in Asian Electronics Industries: UN/ESCAP.

Rodríguez-Clare, A. (1996). Multinationals, linkages, and economic development. American Economic Review, 86(4): 852-73.

Scott-Kennel, J. (2004). Foreign direct investment: A catalyst for local firm development? The European Journal of Development Research, 16(3): 624-52.

Sjöholm, F. (1999). Technology gap, competition and spillovers from direct foreign investment: Evidence from establishment data. The Journal of Development Studies, 36(1): 53-73.

Supapol, A.B. (1995). Transnational Corporations and Backward Linkages in Asian Electronics Industries. New York: UNESCAP: United Nations Conference on Trade and Development, Economic and Social Commission for Asia and the Pacific. Monograph No. 5.

Turok, I. (1993). Inward investment and local linkages: How deeply embedded is 'Silicon Glen'? Regional Studies, 27(5): 401-17.

UNCTAD. (1998). World Investment Report 1998: Trends and Determinants. New York and Geneva: United Nations.

UNCTAD. (2001). World Investment Report 2001: Promoting Linkages. New York and Geneva: United Nations.

UNCTAD. (2003). World Investment Report 2003: FDI Policies for Development: National and International Perspectives. New York, Geneva: United Nations. 
UNCTAD. (2005). World Investment Report 2005: TNCs and the Internationalization of R\&D. New York, Geneva: United Nations.

UNCTAD. (2006). World Investment Report 2006: FDI from Developing and Transition Economies, Implications for Development. New York, Geneva: United Nations.

UNCTC. (1981). Transnational Corporation Linkages in Developing Countries: The Case of Backward Linkages via Subcontracting, a Technical Paper on Automobile Sector in Peru, India and Morocco. New York: United Nations Centre for Transnational Corporations.

Wong, P.K. (1991). Technological Development through Subcontracting Linkages - A Case Study: Asian Productivity Organization, Faculty of Business Administration, National University of Singapore. 